\title{
THE SPECIFICITY OF THE NATIONAL IDENTITY IN THE EPOCH OF GLOBALIZATION
}

\author{
Anatol Liahchylin, Tatsiana Astrouskaya \\ Department of Philosophy of Culture, \\ Belarusian State University, \\ Nezavisimosti Av. 4, Minsk 220030, Belarus \\ E-mail: philcult@bsu.by
}

\begin{abstract}
This article is devoted to the analysis of the national identity in the epoch of globalization. With the impact of globalization things and relations have changed rapidly. The authors try to show that the same situation happened to the national identity, the borders of which are becoming more and more flexible and movable. This situation can be used for the purpose of the renaissance of the national identity. However, it is possible only in the way of the combination of support from the state with realization by every nation of its own specificity and singularity.
\end{abstract}

Keywords: border, globalization, national identity, national state, Republic of Belarus.

DOI: $10.3846 / 2029-0187.2008 .1 .108-112$

In strongest terms it is possible to say that specific historical circumstances are an important reason of cultural and social differences and because of them the differences do not disappear as it was expected when globalization started. Nowadays, at the beginning of the XXI century, such differences are considered as a subject of special investigation. In addition, the term "identity" is used more and more often and becomes more popular.

The concept of identity (from Latin identicus - the same, equal) has become so flexible and mobile, that it can at best be used just as a certain marker in relation to any social phenomenon. The usage of the word "identity" is so popular now that with its help it is possible to analyze the sphere of education, culture, different social, religious, national contradictions, etc. In addition, the identity as a phenomenon first of all reflects a certain reality, the being of our self-consciousness but, at the same time, with the help of it we single out ourselves from the world of everydayness.

As we take the national identity as an example, it is possible to argue about the identity of the modern Poles, Lithuanians, Germans, Belarusians, etc. However, we fix it with the help of our language at the moment of explicating and underlining differences. When we outline: "I am a Belarusian", it means I am not a German, a Pole, a Lithuanian, etc. In some sense the identity has been stipulated by a real border of this or that space. But this space is no more only physical in the epoch of globalization. The identity is impossible without borders, because a border, as it was noted by Martin Heidegger, is not the place where something ends, but it is the place where something starts to exist. Therefore the identification means rather distinguishing than association. Because of that it is specific 
and interesting. Besides, we can notice it on all levels. It is possible to speak about the family and the national identity. It is possible to study European identity or the identity of Latin American residents, investigate Christian or Muslim identity. Nevertheless, it is hardly pertinent here to use any logical criteria with the help of which we could offer one general way of analysis.

The search for identity is inherently connected with the fight for recognition, and it often leads to the claim for one's own oneness, and even to the demonstration of cultural and other types of extremism, and finally to the aggressiveness in the relation to the Other. As we see, the problem of identity is highly multi-polar in its displays and for its solving. There are plenty of variations of its analysis and understanding. The topic is particularly attractive when we try to analyze the process of the national state formation. Alternatively, it is suitable for any other social phenomenon in its historical development; for example, such as European integration, globalization, post-soviet decentralization which have caused new independent identities. The question is how historical memory on the one hand and postmodern context on the other can impact transformation of modern national identities.

Radical historical geopolitical and social changes in the XX century certify the birth of a person with a new outlook, fundamentally different from the previous. Moreover, it happens on the global level. The same situation happens in the modern Belarus as well. In other words, the change of generations is coming. We are all looking for the generation which will be not indifferent to the values of its own culture and nation. Such generation will be able to give a new impact to the renaissance of the national culture, which will get a new level of development and a new content. In this system of values we can try to provide a new understanding to such concepts as "space", "place", "own", "strange", "border", "state", and "nation".

Among the cases of the transformation of identity, in a very general perspective, there are the development and wide expansion of informational technologies (it leads to the interosculation of cultures) as well as the compression of space and time that follows from the previous. The closeness and accessibility of any culture leads to the situation when a lot of different others are present in our semantic space. In addition, as a result it becomes difficult to distinguish one's own and other's. But we know that one's own identity is impossible without the border between mine and other's and correspondingly it is impossible without those who are different from me. In such situation when the identification with one specific nation, which you belong to by birth, becomes more and more problematic, we can define our world as multi-identical. However, at the same time we can observe intensive flashes of national egoism and a nation's unceasing fight for independence and recognition. In Belarus this fight takes place on the level of political parties which have chosen the way of formation of the identity based on collective historical memory. Therefore, it is evident that it is not the time to refuse the identity as one of important personal characteristics. Moreover, we should analyze this identity and take into account all specific circumstances of the new world order, in order to answer the question how national identity is possible in the epoch of globalization. 
Today the national identity could be expressed in the terms of aspiration to form specific state of people's mind and people's social and linguistic orientation. Moreover it includes the terms, related to the above said, of ideology, politics, as well as social theory and practices which treat nation as the basis for the existence of independent state and for the highest form of social unity. The strategy of the Belarusian state can be considered here as a way of building up its own self-sufficient national belonging through the specific relationship to other nations.

Modern Belarusian society can be characterized by the specific state of equality in the sense of belonging to the same political identity (it does not exclude social, economical and even cultural inequalities, of course). Standardized political culture is cultivated by the system of education, culture and distributed among the members of the society. This exposition of the specifics of the modern Belarusian identity can be considered as a symptom, which can help us with the diagnostics of the modern society. The identity is inseparably related to other descriptions of our time and with those changes, which are very evident displays of our epoch. Earlier we spoke rather about different aspects of the identity and about the phenomenon of the Belarusian identity in the context of globalization. Now we will turn to more specific problems and will try to present a point of view from inside.

The identity formation is closely related to the inevitable person's aspiration to order. The topic of the relationship between the order and the identity is very hot in the modern rapidly changing world. The order is often defined as something that ensures more or less possibilities to foreknow the results of our actions and that guarantees the determined safety (Бауман 2002: 24). And normally we start to think about the order when it displays in a wrong form, or even disappears at all.

Nowadays in the situation of late modernity or post-modernity things are changing rapidly. Security and order are no more the main characteristics of our society. We can rather certify full disorder which is cased by unlimited and unprecedented freedom in human history. The lack of usual things order leads to confusion and anxiety. It is impossible to make somebody happy just by the substitution of the order by freedom. According to Zygmunt Bauman, freedom for a human society is integrated with dangers. It can generate as much misfortunes as safety without freedom (Бауман 2002: 78). "Individuals have been offered (or, rather, have been cast into) freedom of unprecedented proportions - but at the price of similarly unprecedented insecurity" (Bauman 2001: 159). Life in insecure conditions means life in risk conditions. And a person who makes decisions has to pay for this risk himself / herself. Normally a person needs at least minimal prediction of what will be tomorrow. It is impossible to live in suddenness. A person tries to supplement the lack of knowledge of what will be tomorrow and accordingly the lack of order by circumscribing himself from the source of unpredictability. As a rule, such method exactly is used in the process of identity construction. Such idea is also very popular among the followers of the Belarusian state politics of identity.

Let us turn now to the problem of the correlation between the state and nation from the point of view of identity. We know that globalization has arisen first of all as an economic phenomenon and this economic component has now influence to any other - cultural or 
social - processes. This economic impact is also one of the reasons of the crisis of traditional national identity and, accordingly, is the reason of the contradictions between cultures. There is an opinion (Zygmunt Bauman, Manuel Castells) that it is the process of globalization that impacts the new status of the national state and leads it to destruction. It is typical especially for a huge number of the new by arisen states, which are all fighting for recognition of their national identity and independence. However, national states are found now in the situation of the dependence on the global capital, which has no attachment to any state and is free in its movements. Global markets now dictate their own rules to the whole planet. The main aspect of this tendency is the loss of the control of internal affair within the state. If earlier a state meant a government body which applies on the basis of its legitimate right and possession of sufficient resources to have the right to establish and guarantee rules and norms on a certain territory, now it is getting more and more difficult to realize legal right of the state on the national safety and sovereignty (i.e. assert its own identity) (Бауман 2002: 112).

National states have to build up international relations now by joining different coalitions. It leads to the gradual loss of the state's sovereignty. However, here we encounter the situation of a paradox. The more we lose our identity, the more power the state system gets, and that has influence on the national identity. Thus, the existence of the national identity is still the actuality, and then we encounter the dilemma of what is primary: the nation (as a certain ethno-cultural formation) in relation to the state or the state in relation to the nation? Therefore, we can certify that the state can be centered without a certain national idea, just be based on citizenship, for example. But the support of the national identity often expresses state's aspiration to strengthen its position and to increase its authority.

It is important to mention essential positive perspectives of globalization in relation to "peripheral" cultures and nations. Such cultures and nations find perspective of social mobility. The process of globalization leads this kind of culture to the idea that the border is an artificial formation and that the border does not play an important role in the process of identification. It is more important that such attitude loses the comprehension of own specificity, which, in spite of that is not an obstacle for any communication. Such sources of communication as Internet in this context are technical components and let this kind of integration come to an end.

\section{Conclusions}

The epoch of globalization - to our mind - is the epoch of the national renaissance. Social explosions at the end of the XX century prove that nations live their own lives in the modern world, embodied in cultural constructs and political projects.

National identity is one of a few remained sources of sense in the modern world. Just therefore, national identity does not become a utopian project but, on the contrary, acquires essentially new possibilities. In other words, a nation acquires a new possibility for self-realization.

As to the national identity, globalization leads to the "plurality of borders", i.e. to the vanishing of the opposition between nationality and internationality (Бек 2003). 
The previous leads to new politics of differentiation: the western version of modernity should not dominate for us, during the evaluation of other cultures. It is important to understand that non-western civilizations represent specific combinations of culture, capital and national state.

\title{
References
}

Bauman, Z. 2001. The Individualized Society. Cambridge: Polity Press.

Бауман, 3. М. 2002. Индивидуализированное общество. Москва: Логос.

Бек, У. 2003. “Космополитическое общество и его враги”, Журнал социологии и социальной антропологии 1(VI): 24-54.

\section{TAUTINĖS TAPATYBĖS SAVITUMAS GLOBALIZACIJOS EPOCHOJE}

\author{
Anatol Liahchylin, Tatsiana Astrouskaya
}

Santrauka

\begin{abstract}
Analizuojama tautinè tapatybė globalizacijos sąlygomis. Globalizacijos procesas savaime sukelia didžiulių valstybės ir tautinio tapatumo pokyčių, tad tapatumo ribos tampa vis lankstesnès. Straipsnio autorių manymu, tokia situacija gali inspiruoti tautinio tapatumo renesansą. Tačiau tai įmanoma tik puoselèjant nacionalinès valstybès unikalumą ir savitumą.
\end{abstract}

Reikšminiai žodžiai: siena, globalizacija, tautinè tapatybė, tautinė valstybė, Baltarusijos Respublika.

Received 23 May 2008, accepted 25 June 2008 